\title{
Structural and Ecophysiological Alterations of the Water Hyacinth [Eichhornia crassipes (Mart.) Solms] Due to Anthropogenic Stress in Brazilian Rivers
}

\author{
Angela Pierre Vitória ${ }^{1 *}$, Frederico Lage-Pinto ${ }^{1}$, Leonardo Bernardo Campaneli da Silva ${ }^{1}$, \\ Maura da Cunha ${ }^{2}$, Jurandi Gonçalves de Oliveira ${ }^{3}$, Carlos Eduardo Rezende ${ }^{1}$, Cristina \\ Maria Magalhães de Souza ${ }^{1}$ and Ricardo Antunes Azevedo ${ }^{4}$ \\ ${ }^{1}$ Laboratório de Ciências Ambientais; Centro de Biociência e Biotecnologia; Universidade Estadual do Norte \\ Fluminense; Av. Alberto Lamego, 2000; Campos dos Goytacazes - RJ - Brasil. ${ }^{2}$ Laboratório de Biologia Celular e \\ Tecidual; Centro de Biociência e Biotecnologia; Universidade Estadual do Norte Fluminense; Av. Alberto Lamego, \\ 2000; Campos dos Goytacazes - RJ - Brasil. ${ }^{3}$ Laboratório de Melhoramento Genético Vegetal; Centro de Ciências e \\ Tecnologias Agropecuárias; Universidade Estadual do Norte Fluminense; Campos dos Goytacazes - RJ - Brasil \\ ${ }^{4}$ Departamento de Genética; Escola Superior de Agricultura Luiz de Queiroz; Universidade de São Paulo, Av. \\ Pádua Dias, 11; Piracicaba - SP - Brasil
}

\begin{abstract}
In this work, the structural and ecophysiological alterations (chlorophyll a fluorescence and photosynthetic pigments), and quantification of $\mathrm{Cr}, \mathrm{Pb}$ and $\mathrm{Zn}$ in the leaf limb, petiole and younger and older roots of water hyacinth from the lower, medium and upper Paraíba do Sul river (PSR) and Imbé river were evaluated. The plants from the medium and upper PSR (more industrialized and populated regions) exhibited lower turgid cell in the root cortex, less root hairs and leaf epidermis, chloroplasts with plastoglobules and increased stroma volume. Higher concentrations of metals were observed in the younger and older roots from the medium PSR plants. The results suggested that the plants from more anthropized regions were able to maintain the maximum quantum yield $\left(F_{v} / F_{m}\right)$ which was a result from the metabolic fitting, increasing the non-photochemical quenching, reducing total chlorophyll/carotenoids and leading to the structural modifications.
\end{abstract}

Key words: chlorophyll $a$ fluorescence, photosynthetic pigments, energy dissipation, morphological alterations, metal evaluate

\section{INTRODUCTION}

The anthropogenic activities have led to the degradation of rivers, resulting in the ecological disequilibrium (Souza et al., 2004; Mangabeira et al., 2004). Water hyacinth [Eichhornia crassipes (Mart.) Solms] has received considerable attention due to its ability to grow in the polluted water environments as well as for tolerating and accumulating the toxic metallic ions and other contaminants (Vesk et al., 1999; Zhu et al., 1999; Lu et al., 2004; Mahammod et al., 2005; Mishra et al., 2007). Even under stressful conditions, this plant usually is able to develop without any visual toxicity symptoms (Lage-Pinto et al., 2008).

\footnotetext{
*Author for correspondence: apvitoria@uenf.br
} 
The influence of pollutants on the plants is commonly studied by the evaluation of biomass production, abundance, growth, pigment contents and enzymatic activity (Vassilev, 2002; Gratão et al., 2005; Gomes-Junior et al., 2007; Gratão et al., 2008; Arruda and Azevedo, 2009). Chlorophyll $a$ fluorescence in vivo analysis has contributed to understand and evaluate the sublethal effects of environmental stress on the photosynthetic activity, although such type of analysis is still modestly used on the study of aquatic photosynthetic organisms (Ralph and Burchett, 1998; Lage-Pinto et al., 2008). Allied to the chlorophyll $a$ fluorescence data, pigments quantification has also contributed to the studies in which the effect of pollutant was evaluated. According to Hendry and Price (1993), variations in the rates of total chlorophyll and carotenoids are good parameters to demonstrate the plant stress. Mishra et al. (2007) observed that water hyacinth plants subjected to $\mathrm{Cd}$ concentrations of $25,50,75$ and $100 \mu \mathrm{g} \cdot \mathrm{ml}^{-1}$ exhibited reduced chlorophyll $a$ and $b$ contents.

The anatomical and ultra-structural studies may be used as a part of the studies on the modifications caused by the potentially toxic metals and other plant pollutants. Anatomical and morphological (Vitória et al., 2004; Mahmmod et al., 2005) as well as ultra-structural (Vitória et al., 2006; LagePinto et al., 2008; Gratão et al., 2009) modifications at chloroplasts level are well known consequences of heavy metals-induced stress.

The rivers of the South and Southeast regions of Brazil have been submitted to an increasing process of degradation, being strongly affected by the anthropogenic activities (Souza et al., 2004; Rodrigues et al., 2009; Siqueira et al., 2009). Paraíba do Sul river (PSR) is a tropical river of medium size with approximately $1,145 \mathrm{~km}$ length and a drainage basin of $55,400 \mathrm{~km}^{2}$ that serves three of the most important and populated Brazilian States. As a consequence, their waters are in constant association with the anthropogenic substances of toxic nature, exposing especially aquatic biota to stressful conditions (Azevedo et al., 2004; Campaneli et al., 2010; Vitória et al., 2010). The investigations on the plant performance in the natural conditions are essential to access the life conditions in contaminated environments. Under this context, water hyacinth has been considered a good model for such studies due to its ability to survive under various environmental circumstances (Mangabeira et al., 2004; Mahmood et al., 2005; Lage-Pinto et al., 2008; Campaneli et al., 2010; Vitória et al., 2010).

In the present study, water hyacinth plants from three regions of PSR, with different contamination levels, and from the Imbé river were studied. The alteration in the chlorophyll $a$ fluorescence, photosynthetic pigments, metal concentrations, morphological and ultra-structural modifications were investigated with the aim to evaluate thewater hyacinth fitting strategies towards undesirable environmental conditions.

\section{MATERIAL AND METHODS}

\section{Collection sites and plant material}

Ten young and healthy water hyacinth [Eichhornia crassipes (Mart.) Solms] plants were collected in September-2006 from the Imbé river in Campos dos Goytacazes city, Rio de Janeiro State, Brazil, (river with reduced human influence) and in three different points in PSR (Fig. 1) over $800 \mathrm{~km}$ : 1) Upper PSR, in São José dos Campos city, São Paulo State, Brazil, with approximately 600,000 inhabitants and a large industrial park (high technology and metallurgy); 2) medium PSR, in Volta Redonda city, Rio de Janeiro State, Brazil, with approximately 460,000 inhabitants and a large industrial park (metallurgy) and 3) lower PSR, in Campos dos Goytacazes city with approximately 430,000 inhabitants, an unindustrialized region where agriculture, mainly sugar-cane cultivation, was the main activity and source of contaminants.

Water hyacinth plants were collected at each site (always at the river margins). Ten plants were sampled at different points along approximately 1 $\mathrm{km}$ and in order to carry out the measurements, the plants were removed from the rivers placed in the containers with water from the river and transported to the laboratory. 


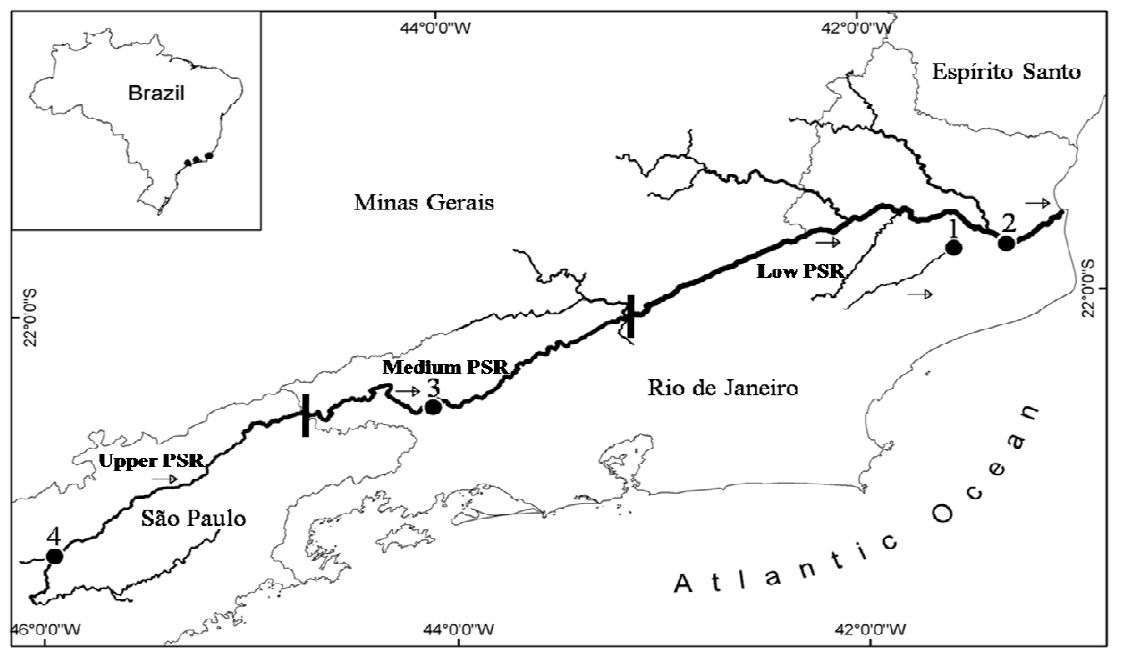

Figure 1 - Water hyacinth collection sites. 1 - Imbé river and 2 - lower PSR (both in Campos dos Goytacazes - RJ), 3 - medium PSR (Volta Redonda - RJ), 4 - upper PSR (São Jose dos Campos - SP). PSR - Paraíba do Sul river. Source: Lage-Pinto et al. (2008).

\section{Chlorophyll $a$ fluorescence parameters}

Chlorophyll a fluorescence parameters were determined between 9:30 a.m. and 11:00 a.m. using a portable modulated pulse fluorimeter (MINI PAM, Walz, Germany). Ten intact, totally expanded and healthy leaves from each collection site were kept in the dark for $30 \mathrm{~min}$ with clamps and exposed to the weak, modulated light beam (approximately $6 \mu \mathrm{mol} \mathrm{m} \mathrm{m}^{-2}$ at $660 \mathrm{~nm}$ ), followed by exposure for $0.8 \mathrm{~s}$ of high intensity $(10000$ $\mu \mathrm{mol} \mathrm{m} \mathrm{m}^{-2}$ ) actinic white light. This methodology was adapted from Genty et al. (1989) and Van Kooten and Snel (1990). The following chlorophyll $a$ fluorescence emission parameters were recorded: $F 0$ (minimal fluorescence), $F \mathrm{~m}$ (maximum fluorescence) and fluorescence quencher coefficients qN and NPQ (nonphotochemical quenching). The $F \mathrm{v}, F \mathrm{v} / F \mathrm{~m}, F \mathrm{v} / F 0$ ratios were calculated and the values are presented as the mean of ten measurements, representing ten replicates.

\section{Photosynthetic pigments}

Three discs were taken from ten plants and used to quantify the photosynthetic pigments. The three discs were sliced and placed in plastic tubes in the dark with a lid containing $5.0 \mathrm{~mL}$ dimethylsulfoxide reagent (DMSO - VETEC, Brazil) as organic solvent. After a five day-period, the extract was analyzed in a spectrophotometer at wavelengths of $480 \mathrm{~nm}, 649 \mathrm{~nm}$ and $665 \mathrm{~nm}$. The photosynthetic pigments were quantified using the equations described by Wellburn (1994) for carotenoids, chlorophyll $a$ and chlorophyll $b$ and the total chlorophyll, chlorophyll $a / b$ and total chlorophyll/carotenoids ratios calculated. All the laboratory procedures were carried out in a low light environment.

\section{Metal content analysis}

Thoroughly washed plants (three times with distilled-deionized water) were separated into leaf limb, petiole and younger (light color and less than $10 \mathrm{~cm}$ ) and older roots (dark color and more than $10 \mathrm{~cm}$ ) and frozen in liquid nitrogen. After freeze drying for $48 \mathrm{~h}$ (LABCONCO 260337 Freeze Dry System) and grinding of the plant parts, $500 \mathrm{mg}$ of ground tissue was digested following a modified version of the procedure used by Krause et al. (1995). The protocol consisted of an acid digestion in Teflon bombs with $10 \mathrm{~mL} \mathrm{HNO}_{3}(65 \%)$ and $10 \mathrm{~mL} \mathrm{HF} \mathrm{(48 \% )}$ for $12 \mathrm{~h}$ at $150^{\circ} \mathrm{C}$. After digestion, the samples were resuspended in $0.5 \mathrm{M} \mathrm{HNO}_{3}$. An atomic emission spectrometer (ICP- AES Varian Techtron) was used to detect the $\mathrm{Zn}, \mathrm{Pb}$ and $\mathrm{Cr}$ elements, and the values were expressed in $\mu \mathrm{g} . \mathrm{g}^{-1}$ dry weight. The detection limits $\left(\mu \mathrm{g} \cdot \mathrm{g}^{-1}\right)$ to $\mathrm{Zn}$, $\mathrm{Pb}$ and $\mathrm{Cr}$ were $0.3,0.3$ and 0.7 , respectively. Standard reference material was analyzed in order to estimate the recovery only for $\mathrm{Zn}$ $(78.5 \%)$ of the digestion method using Apple 
Leaf Reference Standard Material 1515 supplied by the National Institute of Standards and Technology (USA).

\section{Scanning electron microscopy (SEM)}

Leaf and root samples were fixed for two hours in a solution of $2.5 \%$ glutaraldehyde and $4.0 \%$ formaldehyde in $0.05 \mathrm{M}$ cacodylate buffer, $\mathrm{pH} 7.2$, according to Vitória et al. (2003). Subsequently, the samples were rinsed in the same buffer and post-fixed for one hour at room temperature with $1.0 \%$ osmium tetroxide in $0.05 \mathrm{M}$ cacodylate buffer, $\mathrm{pH}$ 7.2. The post-fixed samples were dehydrated in an ascending acetone series (one hour each step). The samples were then submitted to the critical-point-drying method using $\mathrm{CO}_{2}$. Dried samples were placed in the stubs, sputtered with $20 \mathrm{~nm}$ gold, and then observed with a digital scanning electron microscope (DSEM 962 Zeiss).

\section{Light microscopy (LM)}

Root fragments were fixed, post-fixed and dehydrated as described for SEM. Subsequently, the material was embedded in epoxi resin (Polybed). Thin sections $(1.0 \mu \mathrm{m})$ were stained with toluidine blue $(1 \%)$. The glass slides were sealed with Entellan ${ }^{\circledR}$ (Merck) and examined with an Axioplan Zeiss microscope.

\section{Transmission electron microscopy (TEM)}

The leaf fragments were fixed, post-fixed, dehydrated, and embedded as described above. Ultrathin sections $(80 \mathrm{~nm})$ were collected in copper grids (300 mesh) and stained with $1.0 \%$ alcoholic uranyl acetate, followed by $5.0 \%$ aqueous lead citrate. Ultrathin sections were observed at $80 \mathrm{kV}$ using a transmission electron microscope (EM 900 Zeiss).

\section{Statistical analysis}

The data for metal concentrations, chlorophyll $a$ fluorescence parameters and photosynthetic pigments were checked for the normality and variance (Statistic 6.0) and subsequently submitted to variance $t$-test to detect the differences between the collections sites $(p<0.05)$ and between the sites and plant parts for metal concentration $(p<$ 0.05). Pearson's correlation coefficient (r) was calculated between the non-photochemical quenching parameters (NPQ and $\mathrm{qN}$ ) and the concentrations of carotenoids pigments $(n=40)$.

\section{RESULTS}

Results showed that the concentrations of $\mathrm{Cr}, \mathrm{Pb}$ and $\mathrm{Zn}$ were higher in the plants from the medium PRS and lower in the plants from the Imbé river (Table 1). Independent of the sampling location of the plants, these metals were detected in higher concentrations in the roots (young and older) than in the aerial parts (leaf limb and petiole).

Table 1 - Metal concentrations ( $\mu \mathrm{g} . \mathrm{g}^{-1}$ dry matter) in water hyacinth. Upper case letters: different collection point. Lower case letters: different parts of the plant in the same collection point. Means with different letters are significantly different $(p \leq 0.05)$. PSR: Paraíba do Sul river. n.d.: not detected.

\begin{tabular}{cccccc}
\hline & & Imbé river & Lower PSR & Medium PSR & Upper PSR \\
\hline & Leaf Limb & $1.64 \pm 0.25 \mathrm{Ab}$ & n.d. & $0.80 \pm 0.80 \mathrm{Ac}$ & n.d. \\
$\mathrm{Cr}$ & Petiole & $0.80 \pm 0.80 \mathrm{Ab}$ & $1.07 \pm 1.07 \mathrm{Ac}$ & $2.67 \pm 0.49 \mathrm{Ac}$ & n.d. \\
& Younger root & $5.79 \pm 0.78 \mathrm{Ca}$ & $25.3 \pm 0.80 \mathrm{Bb}$ & $39.4 \pm 1.77 \mathrm{Ab}$ & $2.57 \pm 1.38 \mathrm{Cb}$ \\
& Older root & $4.25 \pm 2.00 \mathrm{Da}$ & $30.3 \pm 1.25 \mathrm{Ba}$ & $58.0 \pm 1.00 \mathrm{Aa}$ & $13.8 \pm 0.60 \mathrm{Ca}$ \\
\hline \multirow{4}{*}{$\mathrm{Zn}$} & Leaf Limb & $38.1 \pm 2.93 \mathrm{Bc}$ & $43.4 \pm 2.25 \mathrm{Bb}$ & $122 \pm 6.01 \mathrm{Ad}$ & $42.1 \pm 4.40 \mathrm{Bc}$ \\
& Petiole & $40.6 \pm 1.30 \mathrm{Cc}$ & $57.3 \pm 0.38 \mathrm{Bb}$ & $315 \pm 6.93 \mathrm{Ac}$ & $45.2 \pm 1.34 \mathrm{BCc}$ \\
& Younger root & $69.8 \pm 3.30 \mathrm{Bb}$ & $98.7 \pm 8.06 \mathrm{Ba}$ & $467 \pm 58.4 \mathrm{Ab}$ & $101 \pm 4.10 \mathrm{Bb}$ \\
& Older root & $88.8 \pm 2.00 \mathrm{Ba}$ & $115 \pm 1.28 \mathrm{Ba}$ & $961 \pm 21.0 \mathrm{Aa}$ & $134 \pm 0.16 \mathrm{Ba}$ \\
\hline \multirow{4}{*}{} & Leaf Limb & n.d. & n.d. & n.d. & $3.33 \pm 1.75 \mathrm{Ab}$ \\
$\mathrm{Pb}$ & Petiole & n.d. & n.d. & n.d. & n.d. \\
& Younger root & $1.27 \pm 1.27 \mathrm{Bab}$ & $9.13 \pm 0.58 \mathrm{Aa}$ & $9.80 \pm 1.18 \mathrm{Ab}$ & n.d. \\
& Older root & $4.20 \pm 0.0 \mathrm{Ca}$ & $10.2 \pm 1.12 \mathrm{Ba}$ & $19.9 \pm 0.00 \mathrm{Aa}$ & $11.6 \pm 0.74 \mathrm{Ba}$ \\
\hline
\end{tabular}


The medium and upper PSR plants exhibited the maximum chlorophyll $a / b$ rates and the lowest total chlorophyll/carotenoids rates $(p \leq 0.05)$ (Table 2). Results for the pigments and chlorophyll $a$ fluorescence also showed variation between the sampling locations. $F_{\mathrm{v}} / F_{\mathrm{m}}$ (maximum quantum yield) and $F_{\mathrm{v}} / F_{0}$ ratios were higher in the plants of medium and upper PSR than in the plants of lower PSR and Imbé river $(p \leq 0.05)$. The values of qN and NPQ in the plants sampled in the upper PSR were higher than in the other sites ( $p \leq$ 0.05 , Table 2). Pearsons' correlation between the non-photochemical quenching parameters (qN and NPQ) and carotenoids concentrations revealed a significant correlation $(\mathrm{r}=0.40 ; p=0.007 ; \mathrm{n}=40)$ between the $\mathrm{qN}$ and carotenoids, and nonsignificant correlation $(\mathrm{r}=0.29 ; p=0.061 ; \mathrm{n}=40)$ between the NPQ and this pigment.

Table 2 - Photosynthetic pigments ( \pm standard errors) and chlorophyll $a$ fluorescence parameters ( \pm standard errors) of water hyacinth leaves adapted to the dark. Means with different letters are significantly different $(p \leq 0.05)$. PSR: Paraíba do Sul river.

\begin{tabular}{lcccc}
\hline Parameters & Imbé river & Lower PSR & Medium PSR & Upper PSR \\
\hline Clo $a / b$ & $2.4 \pm 0.10 \mathrm{~b}$ & $2.1 \pm 0.10 \mathrm{~b}$ & $3.2 \pm 0.11 \mathrm{a}$ & $2.9 \pm 0.10 \mathrm{a}$ \\
Clo total/ caro & $4.2 \pm 0.12 \mathrm{a}$ & $4.8 \pm 0.19 \mathrm{a}$ & $3.8 \pm 0.15 \mathrm{~b}$ & $3.8 \pm 0.13 \mathrm{~b}$ \\
$F_{\mathrm{v}} / F_{\mathrm{m}}$ & $0.79 \pm 0.010 \mathrm{~b}$ & $0.77 \pm 0.008 \mathrm{~b}$ & $0.82 \pm 0.006 \mathrm{a}$ & $0.83 \pm 0.004 \mathrm{a}$ \\
$F_{\mathrm{v}} / F_{0}$ & $3.8 \pm 0.2 \mathrm{~b}$ & $3.4 \pm 0.2 \mathrm{~b}$ & $4.5 \pm 0.2 \mathrm{a}$ & $4.8 \pm 0.1 \mathrm{a}$ \\
$\mathrm{qN}$ & $0.023 \pm 0.001 \mathrm{~b}$ & $0.021 \pm 0.001 \mathrm{~b}$ & $0.025 \pm 0.002 \mathrm{~b}$ & $0.033 \pm 0.001 \mathrm{a}$ \\
NPQ & $0.035 \pm 0.002 \mathrm{~b}$ & $0.027 \pm 0.002 \mathrm{~b}$ & $0.034 \pm 0.002 \mathrm{~b}$ & $0.044 \pm 0.003 \mathrm{a}$ \\
\hline
\end{tabular}

TEM images showing chloroplasts from the leaves of water hyacinth sampled in the four regions of the study (three from PSR and one from Imbé river) are shown in Figure 2. In all the images the chloroplasts did not exhibit the signs of thylakoid membrane system disorganization. Starch grains were observed in the majority of samples, except in the leaves from the medium PSR (Figs. $2 \mathrm{C}$ and $\mathrm{G})$, which also showed rearrangement and increase of the stroma to a side of the chloroplasts. A large number of plastoglobules was observed in the plants sampled at upper PSR region (Figs. 2 D and $\mathrm{H}$, arrows).

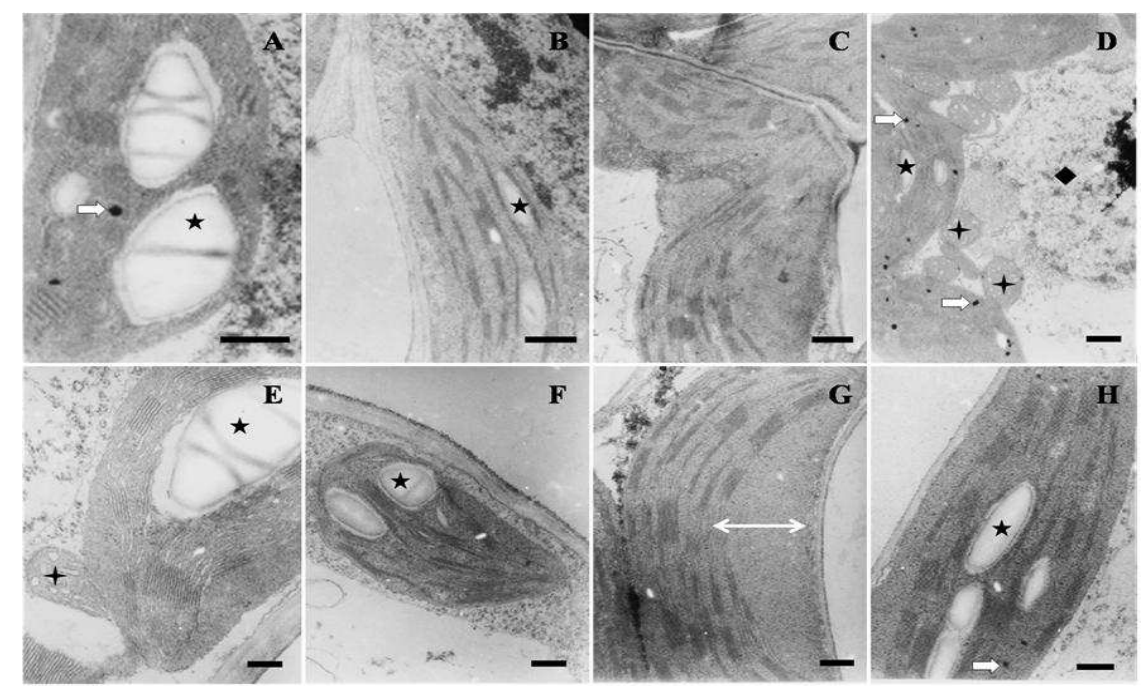

Figure 2 - Transmission Electron Microscopy (TEM) of chloroplasts from water hyacinth. Imbé river (A and E), lower PSR (B and F), medium PSR (C and G), upper PSR (D and H).

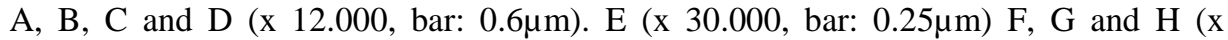

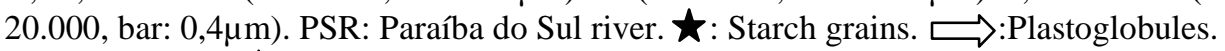
$\longleftrightarrow$ : stroma. $\uparrow$ : mitochondria. $>$ : nuclei. 
The analysis of transversal slices of the roots revealed the presence of calcium oxalate crystals and/or polymers of phenolic nature in the vascular bundle (Fig. 3, arrows). Higher cellular turgidity was observed for the root cells in the samples from the Imbé river and a reduction in the number of the layers of the internal cortical cells from the samples from the medium PSR (Fig. 3C). The morphological analysis of the roots (Fig. 4)in the same samples from the PSR exhibited less turgid radicular hairs (Fig. 4B) when compared to the roots sampled from the Imbé river (Fig. 4A). The major ultrastructural alteration observed through the SEM of epidermal cells from the adaxial foliar tissue were the plasmolysis of the stomatal subsidiary cells and the apparently absence of epicuticular waxes on the samples from the medium PSR (Fig. 4D), when compared to the plant samples from the Imbé river (Fig. 4C).

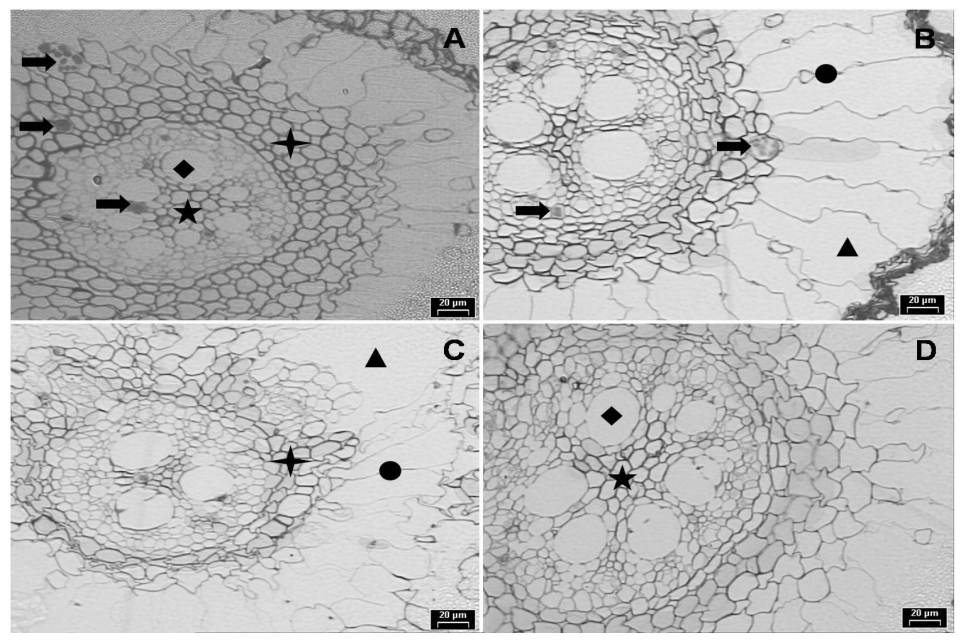

Figure 3 - Transversal section of the absorption region of water hyacinth roots from Imbé river (A), lower PSR (B), medium PSR (C), upper PSR (D). Bar: $20 \mu \mathrm{m}$. PSR - Paraíba do Sul river. $\Delta$ : Aerenchyma. $:$ trabecule. $\triangle$ :xylem. $\downarrow$ : medulla. + : cortex. $\rightarrow$ calcium oxalate crystals.

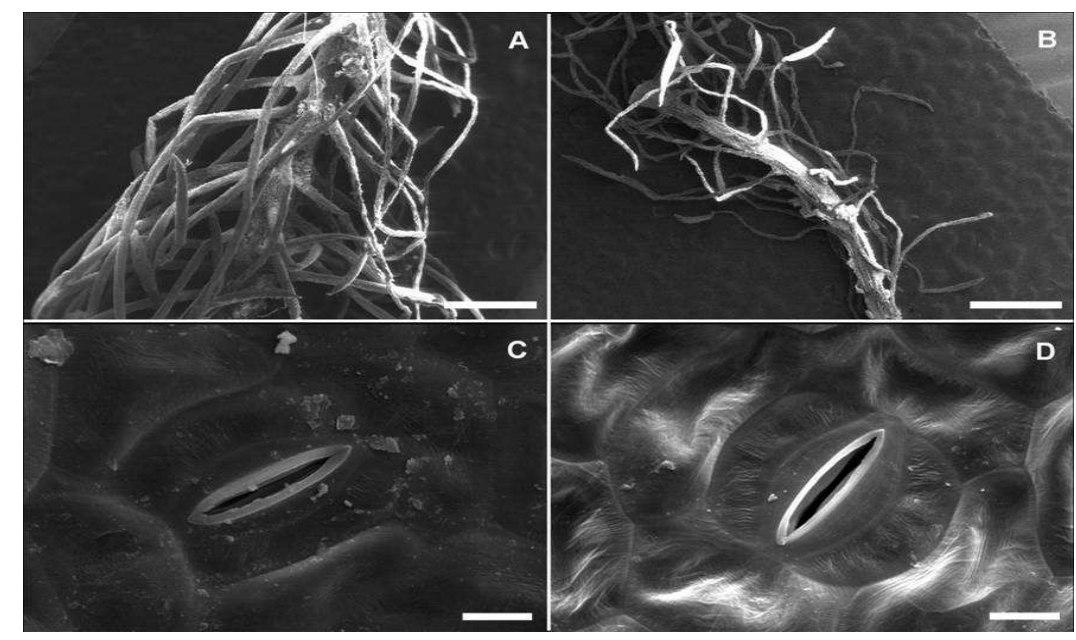

Figure 4 - Scanning Electron Microscopy (SEM) evidencing root (A and B) and stomata (C and D) of the adaxial epidermis in plants of water hyacinth from Imbé river (A and C), and

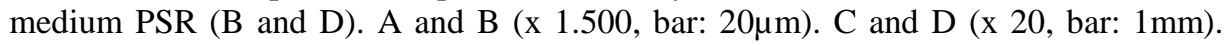
PSR: Paraíba do Sul river. 


\section{DISCUSSION}

Different reports with water hyacinth have shown that most of the metal up-taken by this plant species is accumulated preferentially in the roots (Soltan and Rashed, 2003; Lu et al., 2004; Paiva et al., 2009; Vitória et al., 2010). The accumulation of metals in the root system appears to minimize any major effect on the biomass production and to reduce the harmful symptoms (Verkleij and Prast, 1989). Such strategy occurs with several plants and appears to allow the plants to withstand higher metal concentrations (Vitória et al., 2001; Hu et al., 2010; Monteiro et al., 2011). Although higher $\mathrm{Cr}, \mathrm{Zn}$ and $\mathrm{Pb}$ concentration were observed in the roots from the medium PSR, these values were high enough to be detected in the plants from other polluted rivers (Soltan and Rashed, 2003; Mangabeira et al., 2004; Lu et al., 2004; OlivaresRieumont, 2007).

Chloroplasts ultrastructural analysis suggested that the plants from the medium and upper PSR were under more stressful condition. In the plants originated from the medium PSR, these organelles exhibited increased stroma volume but did not show starch grains (Fig. 2G), which was commonly observed in the chloroplasts from the plants from the other sites sampled. This suggested the utilization of the photosynthetic reserves (stored in the form of starch) in the plants of the medium PSR. The increase in the stroma volume was a typical characteristic of the plants exposed to stress (Bernal et al., 2006; Vitória et al., 2006). For instance, the chloroplasts from the olive plants cultivated near an aluminum (Al) company in Greece exhibited increased stroma volume, which was attributed primarily to the atmospheric pollutants $\mathrm{F}$ (fluor) and $\mathrm{Al}$ (Eleftheriou and Tsekos, 1991).

The plants from the upper PSR presented a larger number of plastoglobules (Fig. 2D), which have been shown to increase in the plants subjected to environmental conditions that induced the oxidative stress. These environmental conditions include, for instance, the increment of $\mathrm{CO}_{2}$ concentrations (Sallas et al., 2003), increment of the ozone concentrations (Britvec et al. 2001), exposure to organic complexes $\mathrm{Ni}(\mathrm{II})$-Glutamate (Molas, 2002), viral infection (Hernandez et al., 2004) and heavy metal (Vitória et al., 2006; Gratão et al., 2009).

Despite the medium and upper PSR being exposed to higher industrial discards and domestic sewage, water hyacinth plants did not exhibit reduction in the maximum quantum yield. The values of $F_{\mathrm{v}} / F_{\mathrm{m}}$ for all the samples analyzed varied between 0.77 and 0.83 . These values were within the limit from 0.75 to 0.85 , suggested by Bolhar-Nordenkampf et al. (1989) as indicative of the plants with photochemical activity from the photosynthesis under normal cell conditions, i.e., the plants that were not under stress. In a study performed by Lage-Pinto et al. (2008) with water hyacinth, the substitution on thylakoids arrangement in grana by lamellae was observed in the plants of the medium PSR. According these authors, this could represent an attempt to maintain the electronic flow, once the lamellae was rich in FSI and poor in FSII, more sensitive to the injuries (Krause and Weiss, 1991).

The rates of $F_{\mathrm{v}} / F_{\mathrm{m}}$ and $F_{\mathrm{v}} / F_{0}$ expresses the efficiency of excitation energy capture by the opened reaction centers of the PS II (Baker, 1991; Krause and Weiss, 1991), indicating the physiological efficiency of the photosynthetic apparatus (Gonçalves et al., 2001) and the photochemical activity of the chloroplasts (Sayed, 2003; Oliveira et al., 2009). In the present study, the variation in $F_{\mathrm{v}} / F_{0}$ ratio was similar to that of the $F_{v} / F_{m}$ ratio (Table 2), reflecting the $\mathrm{PS}_{\text {II }}$ quantum yield, but with a greater amplitude of values. Oliveira et al. (2002) showed that the $F_{\mathrm{v}} / F_{0}$ ratio had a response pattern similar to that of the $F_{\mathrm{v}} / F_{\mathrm{m}}$ ratio in coffee seedlings under chilling stress, but with significantly higher values. Similarly, in water hyacinth exposed to $\mathrm{Cr}^{+3}$ and $\mathrm{Cr}^{+6}$, Paiva et al. (2009) suggested the use of the $F_{\mathrm{v}} / F_{0}$ ratio, rather than the $F_{\mathrm{v}} / F_{\mathrm{m}}$ ratio, for a better discrimination of small differences in the $\mathrm{PS}_{\mathrm{II}}$ quantum yield. The authors observed mean values of $F_{\mathrm{v}} / F_{0}$ and $F_{\mathrm{v}} / F_{\mathrm{m}}$ of 5.26 and 0.82 , respectively, for the control. These values were near to the ones found in the present work, suggesting that these plants werenot under the photochemical stress at the locations under study.

The positive correlation between the carotenoids and $\mathrm{qN}$ reflected the importance of these pigments for the protection of the photosynthetic apparatus due to their action on the dissipation of the thermal energy, avoiding the formation of singlet oxygen at the reaction center of the PSII (Gonçalves et al., 2001; Merzlyak and Solovchenko, 2002; Burns et al., 2003). The increase in the concentration of these pigments was observed when the plants of water hyacinth were exposed to high concentrations of metals (Hu et al., 2007; Mishra 
et al., 2007) and when Halophila ovalis were exposed to herbicides (Ralph, 2000). It is important to empathize that in the present work, this pigment occurred in higher concentrations in the plants of the more anthropogenic influenced environments (medium and upper PSR), suggesting a defense mechanism against the environmental stresses. However, Paiva et al. (2009) did not find any increase in the carotenoids in water hyacinth plants exposed to $\mathrm{Cr}$. Apparently, in this species this would not be an obligate path to assist the energy dissipation in the plants under stress conditions.

Regarding the plant roots, the main site of metal deposition, light microscopy analysis showed a reduction in the cortex cell layers in the roots from the plants sampled in the medium PSR (Fig. 3C). Mahmood et al. (2005) working with this species reported a reduction in the number of cortex layers in the roots from the plants submitted to textile industrial wastes, which allowed to correlate such modifications with the metals from the industrial wastes. This reinforced the idea that in the region of medium PSR, the plants would be exposed to a higher concentration of xenobiotics when compared to the other sites studied. The SEM images from these roots revealed lower cellular turgor and reduction in the root hair numbers in the plants from the medium PSR (Fig. 4B) and upper PSR (image not shown) when compared with the plants of the Imbé river (Fig. 4A) and low PSR (image not shown). However, Vitória et al. (2003) reported that the roots of radish plants exposed to $\mathrm{Cd}$ for $48 \mathrm{~h}$ increased the number of root hairs when compared to the control, suggesting that this could be a strategy to increase the water absorption in these plants. It was possible that in the present study the plants sampled exhibited morphological alterations as a result of a long term exposure to the adverse environment, whereas Vitória et al. (2003) subjected the radish plants to a short period of exposure to $\mathrm{Cd}$.

The leaves from the plants of the Imbé river (Fig. 4C) and low PSR (image not shown) showed turgid epidermis and with probable deposits of cuticular wax and microorganisms associated, contrasting with the images of epidermis from leaves of the plants from the medium PSR (Fig.4D) and upper PSR (images not shown), less turgid and apparently deprived of cuticular protection. Bytnerowicz et al. (1998), while evaluating the effect of exposing Pinus ponderosa to nitric acid vapors $\left(\mathrm{HNO}_{3}\right)$ for a $12 \mathrm{~h}$ period, observed cuticle deterioration with the $50 \mathrm{ppb}$ $\mathrm{H}^{15} \mathrm{NO}_{3}$ treatment, apart from the disintegration of the wax layer at a concentration of $200 \mathrm{ppb}$ $\mathrm{H}^{15} \mathrm{NO}_{3}$. According to Liu (2006), besides being a barrier to protect the plants from the mechanical damages, desiccation and microbial invasion, wax layers have an important role in resistance against the xenobiotics. Liu (2006) reported that, despite the impression given by guard-cells of an easy entrance point for xenobiotics, only a reduced portion of these xenobiotics from the leaf surface were able to enter through the stomatal aperture.

It is important to highlight that in the present work, under natural conditions, it was impossible to isolate the effect of any chemical compound as responsible for the modifications observed. The Imbé river, although located in a more preserved area than the PSR, deservedawareness about the atmospheric deposition evaluation resulting from the sugarcane plantations. However, there was no doubt about the higher anthropogenic influence in the region of the medium PSR due to its big industrial park, followed by the upper PSR, with its developed technological-industrial region. Under such context, PSR was exposed to various contaminants originated from the incorrect use of non-treated effluents and from agro-chemicals (Azevedo et al., 2004).

Thus, the results reported here suggested a better characterization of environmental stress when associating the metal quantification to other evaluations, such as the physiology of the biota organisms, as a more realistic way to understand the life conditions in the ecosystem. Ecophysiological parameters investigated in this study for water hyacinth exhibited key changes, although the ratios $F_{\mathrm{v}} / F_{\mathrm{m}}$ and $F_{\mathrm{v}} / F_{0}$ suggested that none of the plants were under a clearly established stressful condition when the photochemical activity was considered. However, other results showed higher metal concentrations, morphoanatomical and ultra-structural modifications in the plants from the medium and upper PSR, indicating an effect of human activities on these plants. Strategies as the increase of heat dissipation, observed in the plants from the upper PSR, and increase of carotenoids concentration in relation to the total chlorophylls concentration in the plants from the medium and upper PSR, could be contributing to maintain the quantum yield of this species in a disturbed environment. 


\section{ACKNOWLEDGEMENTS}

This work was funded by FAPESP (Grant $n^{\circ} 04 / 15012-5$ ), CNPq (Grant $n^{\circ}$ 471091/2004-9), INCT/CNPq (Grant $\mathrm{n}^{\circ}$ 573.601/2008-9). The authors want to thank FAPERJ/UENF by the scholarship granted to the second and third authors; to Dr. Denise Klein by the invaluable help with Transmission Electron Microscopy and Arizolli Antônio Rosa for the analysis of metals.

\section{REFERENCES}

Arruda, M.A.Z., Azevedo, R.A. (2009), Metallomics and chemical speciation: towards a better understanding of metal-induced stress in plants. Ann. Appl. Biol., 155, 301-307.

Azevedo, D.A., Gerchon, E., Reis, E.O. (2004), Monitoring of Pesticides and polycyclic Aromatic Hydrocarbons in Water from Paraíba do Sul river, Brazil. J. Braz. Chem. Soc., 15, 292-299.

Baker, N.R. (1991), A possible role for photosystem II in environmental perturbations of photosynthesis. Physiol. Plant., 81, 563-570.

Bernal, M., Ramiro, M.V., Cases, R., Picorel, R., Yruela, I. (2006), Excess copper effect on growth, chloroplast ultrastructure, oxygen-evolution activity and chlorophyll fluorescence in Glycine max cell suspensions. Physiol. Plant., 127, 312-325.

Bolhàr-Nordenkampf, H.R., Long, S.P., Baker, N.R. (1989), Chlorophyll fluorescence as probe of the photosynthetic competence of leaves in the field: a review of current instrument. Funct. Ecol., 3, 497-514.

Britvec, M., Reichenauer, T., Soja, G., Ljubesic, N., Eid, M., Pecina, M. (2001), Ultrastructure changes in grapevine chloroplasts caused by increased tropospheric ozone concentrations. Biologia (Bratisl.), 56, 417-424.

Burns, J., Fraser, P.D., Bramley, P.M. (2003), Identification and quantification of carotenoids, tocopherols and chlorophyll in commonly consumed fruits and vegetables. Phytochemistry, 62, 939-947.90.

Bytnerowicz, A., Percy, K, Riechers, G., Padgett, P., Krywult, M. (1998), Nitric acid vapor effects on forest trees - deposition and cuticular changes. Chemosphere, 36, 697-702.

Campaneli, L.B., Souza, C.M.M., Ribeiro, T.S., Rezende, C.E., Azevedo, R.A., Almeida, M.G., Vitória, A. P. (2010), Variação espaço-temporal de metais em aguapé [Eichhornia crassipes (Mart.) Solms)] material particulado aderido às raízes de aguapé e no sedimento em dois rios do sudeste brasileiro. Biotemas, 23 (4), 119-128.

Eleftheriou, P.E., Tsekos, I. (1991), Fluoride effects on leaf cell ultrastructure of olive trees growing in the vicinity of the Aluminium Factory of Greece. TreesStruc. Funct., 5, 83-89.

Genty, B., Briantais, J-M., Baker, N.R. (1989), The relationship between the quantum yield of photosynthetic electron transport and quenching of chlorophyll fluorescence. Biochem. Biophys. Acta., 990, 87-92.

Gomes-Junior, R.A., Gratão, P.L., Gaziola, S.A., Mazzafera, P., Lea, P.J., Azevedo, R.A. (2007), Selenium-induced oxidative stress in coffee cell suspension cultures. Funct. Plant Biol. 34, 449-456.

Gonçalves, J.F.C., Marenco, R.A., Vieira, G. (2001), Concentration of photosynthetic pigments and chlorophyll fluorescence of mahogany and tonka bean under two light environments. Rev. Bras. Fisiol. Veg., 13, 149-157.

Gratão. P.L., Polle, A., Lea, P.J., Azevedo, R.A. (2005), Making the life of heavy metal-stresses plants a little easier. Funct. Plant Biol., 32, 481-494.

Gratão, P.L., Monteiro, C.C., Antunes, A.M., Peres, L.E.P., Azevedo, R.A. (2008), Acquired tolerance of tomato (Lycopersicon esculentum cv. Micro-Tom) plants to cadmium-induced stress. Ann. Appl. Biol., 153, 321-333.

Gratão, P.L., Monteiro, C.C., Rossi, M.L., Martinelli, A.P., Peres, L.E.P., Médici, L.O., Lea, P.J., Azevedo, R.A. (2009), Differential ultrastructural changes in tomato hormonal mutants exposed to cadmium. Environ. Exp. Botany, 67, 387-394.

Hendry, G.A.F., Price, A.H. (1993), Stress indicators: chlorophylls and carotenoids. In: Hendry, G.A.F., Grime, J.P. (Eds), Methods in Comparative Plant Ecology. Chapman and Hall (London) pp. 148-152.

Hernandez, J.A., Rubio, M., Olmos, E., Ros-Barcelo, A., Martinez-Gomez, P. (2004), Oxidative stress induced by long-term plum pox virus infection in peach (Prunus persica). Physiol. Plant., 122, 486-495.

Hu, C., Zhang, L., Hamilton, D., Zhou, W., Yang, T., Zhu, D. (2007), Physiological responses induced by copper bioaccumulation in Eichhornia crassipes (Mart.). Hydrobiologia, 579, 211-218.

Hu, J., Zheng, A., Pei, D., Shi, G. (2010), Bioaccumulation and Chemical Forms of Cadmium, Copper and Lead in Aquatic Plants. Braz. Arch. Biol. Technol., 53 (1), 235 240.

Krause, G.H., Weis, E. (1991), Chlorophyll fluorescence and photosynthesis: the basics. Ann. Rev. Plant Physiol. Plant Mol. Biol., 42, 313-349.

Krause, P., Erbsloh, B., Niedergesab, R., Pepelnik, R., Prange, A., (1995), Comparative study of different digestion procedures using supplementary analytical methods for multielement-screening of more than 50 elements in sediments of the river Elbe. Fresenius $J$. Anal. Chem., 353, 3-11.

Lage-Pinto, F., Oliveira, J.G., Da Cunha, M., Souza, C.M.M., Rezende, C.E, Azevedo, R.A., Vitória, A.P. (2008), Chlorophyll $a$ fluorescence and ultrastructural changes in chloroplast of water hyacinth as indicators of environmental stress. Environ. Exp. Bot., 64, 307-313.

Liu, Z. (2006), Leaf Epidermal Cells: A Trap for Lipophilic Xenobiotics. J. Integ. Plant Biol., 48, $1063-1068$

Lu, X., Kruatrachue, M., Pokethitiyook, P., Homyok, K. (2004), Removal of cadmium and Zinc by Water Hyacinth Eichhorrnia crassipes. Sci. Asia, 30, 93-103. 
Mahmood, Q., Zheng, P., Siddiqi, M., Islam, E., Azim, M., Hayat, Y. (2005), Anatomical studies on water hyacinth (Eichhornia crassipes (Mart.) Solms) under the influence of textile wastewater. J. Zhejiang University Sci., 6, 991-998.

Mangabeira, P.A.O., Labejof, L., Lamperti, A., De Almeida, A.A.F., Oliveira, A.H., Escaig, F., Severo, M.I.G., Silva, D.C., Saloes, M., Mielke, M.S., Lucena, E.R., Martins, M.C., Santana, K.B., Gavrilov, K.L., Galle, P., Levi-Setti, R. (2004), Accumulation of chromium in root tissues of Eichhornia crassipes (Mart) Solms. In Cachoeira River - Brazil. Appl. Surf. Sci., 231, 497-501.

Merzlyak, M.N., Solovchenko, A.E. (2002), Photostability of pigments in ripening apple fruit: a possible photoprotective role of carotenoids during plant senescence. Plant Sci., 163, 881-888.

Mishra, K.K., Raí, U.N., Prakash, O. (2007), Bioconcentration and Phytotoxicity of Cd in Eichhornia crassipes. Environ. Monit. Assess., 130, 237-243.

Molas, J. (2002), Changes of chloroplast ultrastructure and total chlorophyll concentration in cabbage leaves caused by excess of organic $\mathrm{Ni}(\mathrm{II})$ complexes. Environ. Exp. Bot., 47, 115-126.

Monteiro, C.C., Carvalho, R.F., Gratão, P.L., Carvalho, G., Tezotto, T., Medici, L.O., Peres, L.E.P., Azevedo, R.A. (2011), Biochemical responses of the ethyleneinsensitive Never ripe tomato mutant subjected to cadmium and sodium stresses. Environ. Exp. Bot., 71, 306-320.

Olivares-Rieumont, S., Lima, S., De la Rosa, D., Gram, D.W., Columbie, I., Santana, J.L., Sánchez, M.J. (2007), Water hyacinths (Eichhornia crassipes) as indicators of heavy metal impact of a large landfill on the Almendares River near Havana, Cuba. Bull. Environ. Contam. Toxicol. 79, 583-587.

Oliveira, J.G., Alves, P.L.C.A., Magalhães, A.C.N. (2002), The effect of chilling on the photosynthetic activity in coffee (Coffea arabica L.) seedlings: The protective action of chloroplastid pigments. Braz. J. Plant Physiol., 14, 95-104.

Oliveira, J.G., Alves, P.L.A.C., Vitória, A.P. (2009), Alterations in chlorophyll $a$ fluorescence, pigment concentrations and lipid peroxidetion to chilling temperature in coffee seedlings. Environ. Exp. Bot., 67, 71-76.

Paiva, L.B., Oliveira, J.G., Azevedo, R.A., Ribeiro, D.R.; Silva, M.G., Vitória, A.P. (2009), Ecophysiological responses of water hyacinth exposed to $\mathrm{Cr}^{+3} \mathrm{e} \mathrm{Cr}^{+6}$. Environ. Exp. Bot., 65, 403-409.

Ralph, P.J. (2000), Herbicide tocicity of Halophila ovalis assessed by chlorophyll $a$ fluorescence. Aquat. Bot., 66, 141-152.

Ralph, P.J., Burchett, M.D. (1998), Photosynthetic response of Halophila ovalis to heavy metal stress. Environ. Pollut., 103, 91-101.

Rodrigues, R.P.; Knoppers, B.A.; Souza, W.F.L.; Santos, E.S. (2009), Suspended Matter and Nutrient Gradients of a Small-Scale River Plume in Sepetiba Bay, SEBrazil, Braz. Arch. Biol. Technol., 52 (2), 503-512.
Sallas, L., Luomala, E.M., Utriainen, J., Kainulainen, P., Holopainen, J.K. (2003), Contrasting effects of elevated carbon dioxide concentration and temperature on Rubisco activity, chlorophyll fluorescence, needle ultrastructure and secondary metabolites in conifer seedlings. Tree Physiol., 23, 97-108.

Sayed, O.H. (2003), Chlorophyll fluorescence as a tool in cereal crop research. Photosynthetica, 41, 321-330.

Siqueira, A., Godinho, M.J.L., Kolm, H.E., Machado, E.C. (2009), Evaluation of the Water Quality of Tidal Creeks of Pontal do Paraná, Paraná, Brazil. Braz. Arch. Biol. Technol., 52 (2), 483-492.

Soltan, M.E., Rashed, M.N. (2003), Laboratory study on the survival of water hyacinth under several conditions of heavy metal concentrations. Adv. Env. Res., 7, 321334.

Souza, W. P., Carvalho, C.E.V., Carvalho, C.C.V., Suzuki, M.S. (2004), Mercury and organic carbon distribution in six lakes from the North of Rio de Janeiro State. Braz. Arch. Biol. Tech., 47, 139-145.

Van Kooten, O., Snel, J.F.H. (1990), The use of chlorophyll fluorescence nomenclature in plant stress physiology. Photosynth. Res., 25, 147-150.

Vassilev, A. (2002), Use of chlorophyll fluorescence in phytotoxicity testing: II. Use of parameters at steadystate photosynthesis. J. Environ. Protec. Ecol., 3, 907912.

Verkleij, J.A.C., Prast, J.E. (1989), Cadmium tolerance and co-tolerance in Silene vulgaris (Moench.) Garcke [= S. cucubalus (L.) wilb.]. New Phytol., 111, 637-645.

Vesk, P.A., Nockolds, C.E., Allaway, W.G. (1999), Metal localization in water hyacinth root from an urban rainyland. Plant Cell Environ., 22, 149-158.

Vitória, A.P., Lea, P.J., Azevedo, R.A. (2001), Antioxidant enzymes responses to cadmium in radish tissues. Phytochemistry, 57, 701-710.

Vitória, A.P., Rodrigues, A.P.M., Da Cunha, M., Lea, P.J., Azevedo, R.A. (2003), Structural change in radish seedlings exposed to cadmium. Biol. Plant., 47(4), 561568.

Vitória, A.P., Da Cunha, M., Azevedo, R.A., (2006), Ultrastructural changes of radish leaf exposed to cadmium. Environ. Exp. Bot., 58, 47-52.

Vitória, A.P., Lage-Pinto, F., Campaneli, L.B., Almeida, M.G., Souza, C.M.M., Rezende, C.E., Azevedo, R.A., Oliveira, J.G. (2010), Ecophysiological adaptation and metal accumulation in water hyacinth from two tropical rivers. Braz. J. Plant Physiol., 22(1): 49-59.

Wellburn, A.R. (1994), The spectral determination of chlorophylls $a$ and $b$, as well as total carotenoids, using various solvents with spectrophotometers of different resolution. J. Plant Physiol., 144, 307-313.

Zhu, Y.L., Zayed, A.M., Qian, J.H. De Souza, M., Terry, N. (1999), Phytoaccumulation of trace elements by wetland plants: II. Water Hyacinth. J. Env. Qual., 28, 339-344.

Received: July 27, 2010; Revised: March 24, 2011; Accepted: August 09, 2011. 